\title{
Artigo
}

\section{Alexis de Tocqueville e os fundamentos cívicos da democracia na América} Alexis de Tocqueville and civic foundations of democracy in America

\author{
Dejalma Cremonese \\ Professor do Departamento de Ciências Sociais da Universidade Federal de \\ Santa Maria \\ E-mail: <dcremoisp@yahoo.com.br>
}

Resumo: A presente exposição tem como objetivo, a partir da perspectiva de Alexis de Tocqueville, abordar as concepções deste intelectual acerca do conceito de democracia e igualdade na área social e as relações existentes entre o governo democrático e os aspectos religiosos, educacionais, étnicos e cívicos da sociedade norte-americana. Diante disso, tomou-se como referencial a obra A democracia na América (De La Démocratie en Amérique), cujo primeiro volume foi impresso em 1835 e o segundo, em 1840, e utilizado o paradigma metodológico do ponto de vista analítico-descritivo.

Palavras-chaves: Democracia; Igualdade; Liberdade; Capital social.

\begin{abstract}
The present paper intends to treat, from the perspective of Alexis de Tocqueville, the concepts of this intellectual about democracy and equality, in social area, and the relations between democratic government and religious, educational, ethnics and civic aspects of the American society. Therefore, his book entitled Democracy in America (De La Démocratie en Amérique), whose first volume was printed in 1835 and the second in 1840, was used as a reference, developing the essay through the methodological paradigm of analytic-description.
\end{abstract}

Keywords: Democracy; Equality; Freedom; Social capital.

\section{Introdução}

O presente artigo traz como proposta central de estudo a cultura democrática americana na concepção de um de seus mais conhecidos pesquisadores - o intelectual francês Alexis de Tocqueville (1805-1856). Tocqueville, pioneiro no estudo sociológico, ocupou-se em descrever os hábitos, os costumes e a organização social e política dos 
americanos, para depois tratar da estrutura de dominação, suas instituições políticas e relações existentes entre o Estado e a sociedade civil. Como um visionário, ao abordar o conceito de democracia, apresentou-o de maneira inédita como um processo universal, consistindo num movimento irrefreável: a entrada dos homens na era da igualdade.

As teses de Tocqueville a respeito da democracia americana são estudadas aqui a partir de seus dois textos mais referidos: The American democracy ("A democracia na América", publicado em dois tomos: em 1835 e em 1840), que the rendeu o maior prestígio, e L'ancien regime et la revolución ("O antigo regime e a revolução"), em que faz um contraponto tardio, já no final da vida, da cultura política no Novo Mundo com as vicissitudes políticas da Europa revolucionária, reafirmando algumas de suas máximas sobre a democracia. Além do estudo e análise dos referidos textos, o artigo apóia-se em alguns comentadores contemporâneos, como Aron (1982), Chevallier (1986) e Putnam (2002). ${ }^{1}$

Todo o empreendimento da construção de sua magnum opus "A democracia na América" foi o de tentar responder à seguinte indagação: por que nos Estados Unidos a sociedade democrática é liberal e eficaz? Diversos pensadores, ao longo dos séculos, retomaram esta questão. No estudo político contemporâneo, como em Robert Putnam, foi retomada esta problemática, na busca por compreender, a partir dela, tudo aquilo que é favorável e benéfico ao regime democrático - como a prática comum de participação comunitária na tomada de decisões. Neste ínterim, o presente texto propõe-se a discorrer acerca de alguns dos elementos constitutivos do processo democrático contemporâneo. Destarte, Tocqueville é não somente uma referência basilar de estudo do tema, como também um orientador metodológico um pensador que mantém, mesmo depois de dois séculos, sua importância na área.

Sendo assim, o artigo tem como objetivo principal resgatar as principais ideias de Tocqueville em relação aos fundamentos cívicos da democracia, o que Robert Putnam, mais tarde denominará capital social. Utilizando um método analítico-descritivo, encontra-se estruturado da seguinte forma: a primeira seção faz uma breve apresentação biográfica do autor e seu contexto, enumerando seus trabalhos de maior relevância. A segunda seção traz a principal tese elaborada pelo autor a partir destas pesquisas: a ideia da democracia como um advento inevitável. A terceira seção trata dos aspectos exteriores da América do Norte, como as origens étnicas e as diferenças políticas

Conferir, igualmente, o artigo intitulado "Tocqueville: sobre a liberdade e a igualdade", de Célia Galvão Quirino (2001), em que a autora comenta as principais ideias da obra A democracia na América (149-188). 
e sociais entre o Sul e o Norte. Na quarta seção, trata das características que estes elementos dão à democracia dos americanos, como o caráter associativista e comunitários entre os seus habitantes, tese que instigou Robert Putnam a tratar do tema capital social em seus estudos contemporâneos. Na quinta e última seção, o artigo aborda a visão culturalista de Tocqueville, aspectos religiosos e educacionais e sua relação com a democracia norte-americana.

\section{Tocqueville: um entusiasta da democracia}

Filho de uma família de aristocratas, Alexis de Tocqueville nasceu em Paris no dia 29 de julho de 1805 e faleceu em Cannes no dia 16 abril de 1859 antes de completar 54 anos de idade. Seu bisavô materno foi degolado durante a Revolução Francesa. Seu pai foi preso por um ano e escapou da morte porque Robespierre, liderança do período revolucionário francês correspondente ao Terror, veio a falecer momentos antes, no ano de 1794. Tocqueville nasceu sob a dinastia de Napoleão e viveu na França pós-revolucionária. Estudou Direito em Paris, tendo por inspirações e influências pensadores como Rousseau, Montesquieu e Pascal. ${ }^{2}$

Em 1830, com 25 anos de idade, por razões ainda desconhecidas, recebeu a incumbência do Rei Luís Felipe para ir aos Estados Unidos da América estudar o sistema penitenciário daquele país. A viagem de Tocqueville, juntamente com seu amigo Gustave de Beaumont, durou de maio de 1831 a fevereiro de 1832. Depois de menos de um ano de estudos in loco, Tocqueville acabou tornando-se um célebre conhecedor do funcionamento do regime político e da vida sociopolítica dos norte-americanos. Viajou ao norte, Nova Inglaterra e, ao sul, esteve em New Orleans e foi até a região dos Grandes Lagos - Michigan. Como síntese dos seus estudos, surgiu a sua principal obra, A democracia na América (De La Démocratie en Amérique), cujo primeiro volume foi impresso em 1835, quando contava apenas 30 anos de idade, e o segundo em 1840. Por ironia, o maior livro sobre a democracia americana foi escrito por um aristocrata francês.

Jean-Jacques Rousseau foi eminente filósofo iluminista, da linhagem dos "contratualistas", do século XVIII. Exerceu vasta produção em diversas áreas do saber, legando importantes contribuições para a política e a educação. Montesquieu foi importante cientista político do século XVIII. É famoso por ter postulado a divisão dos "três poderes", ainda hoje empregada na conjuntura dos modernos estados democráticos de direito. Pascal é considerado o filósofo religioso do século XVI. É famoso pela frase: "O homem é um caniço mais fraco da natureza, mas é um junco pensante". 
Possivelmente a obra A democracia na América seja um dos mais importantes trabalhos sobre a democracia do qual temos acesso. Quanto ao espectro político, Tocqueville é de difícil definição, como bem expressou Raymond Aron (1982): "Demasiado liberal para o partido de onde ele provém, não muito entusiasta por ideias novas aos olhos dos republicanos, ele não foi adotado nem pela direita nem pela esquerda, ele permanece suspeito a todos". 3 Tendo realizado incursões políticas, sendo eleito deputado, Tocqueville também ocupou o cargo de ministro de Estado, acabando por abandonar a carreira política mais tarde, ao perceber que não tinha vocação para tal empreitada.

A intenção da viagem para a América com o objetivo de estudar o sistema carcerário americano foi apenas um pretexto. O que Tocqueville realmente queria era conhecer a experiência democrática dos americanos, já alardeada aos quatro cantos do mundo como o mais novo sucesso dos regimes políticos. E mais, se Tocqueville escrevera a sua principal obra aos 30 anos, pelo menos dez anos antes, aos 20, o tema da democracia já Ihe instigava a curiosidade. Assim, com apurada antecedência possuía o jovem aristocrata a ideia do livro que iria escrever dez anos mais tarde. Sua ida à América pode ser interpretada como uma viagem para ratificar as convicções de outrora. Viajou para confirmar as hipóteses que tinha levantado uma década antes e extrair os ensinamentos fundamentais: "Não é apenas para satisfazer a uma curiosidade, de resto legítima, que examinei a América; quis encontrar ali ensinamentos que pudéssemos aproveitar" (Tocqueville, 2005: 19). Tocqueville é considerado um dos grandes teóricos da democracia moderna. Para Gaspar (2005: 1), a sua originalidade foi ter identificado o movimento democrático como a mudança decisiva. "Na sociologia política de Tocqueville, a modernidade não se caracteriza essencialmente nem pela indústria, como quer Comte, nem pelo capitalismo e pela luta de classes, como quer Marx, mas pela 'igualdade social das condições'”.

Percebe-se disso, que em Tocqueville, mais do que em outros pensadores do período, encontra-se subjacente a ideia de uma democracia inevitável. À exposição desse tema, central nas formulações de A Democracia na América, dedica-se a próxima seção.

O sociólogo francês Raymond Aron, um dos principais comentadores do autor, foi o responsável por reabilitar a teoria da democracia de Tocqueville na segunda metade do século XX. 


\section{O advento e a inevitável consolidação da democracia}

Desde a gênese do lluminismo e a efervescência das revoluções burguesas, os homens caminhavam rumo a uma sociedade mais democrática. Em determinados cenários, eclodia uma democracia liberal. Em outros, de maneira mais sutil, nascia um liberalismo parcialmente conservador. Mas, independente da forma com que se apresentava, a democracia se instalava aos poucos, e a projeção de Tocqueville se confirmava no decorrer dos anos.

Tocqueville atribuiu um caráter "sagrado" à democracia ao afirmar que querer detê-la seria como lutar contra o próprio Deus, só restando às nações acomodar-se ao estado social que lhes impõe a Providência. ${ }^{4}$

Sobre a democracia entre os gregos, Tocqueville tem a seguinte ideia:

[...] Em Atenas, todos os cidadãos participavam dos negócios públicos, mas não havia mais que vinte mil cidadãos em mais de trezentos e cinquenta mil habitantes: todos os outros eram escravos e cumpriam a maior parte das funções que hoje pertencem ao povo e até a classe média. Atenas, com seu sufrágio universal, não passava pois, afinal de contas, de uma república aristocrática, em que todos os nobres tinham igual direito ao governo (Tocqueville, 2000: 71).

Por outro lado, Tocqueville buscava de certa forma enviar uma resposta aos seus conterrâneos que, na época, dedicavam-se em restaurar a monarquia na França. Pedia incessantemente que seguissem o exemplo da democracia dos Estados Unidos da América, pois acreditava de maneira acertada que aquele país cedo ou tarde dominaria parte do mundo. Dizia Tocqueville: "Parece-me indubitável que, mais cedo ou mais tarde, chegaremos, como os americanos, à igualdade quase completa das condições" (2005: 19). Além disso, Tocqueville anteviu acertadamente o domínio dos Estados Unidos em boa parte do mundo um século mais tarde:

Há hoje na terra dois grandes povos que, partindo de pontos diferentes, parecem avançar rumo ao mesmo objetivo: os russos e os anglo-americanos. Ambos cresceram na obscuridade e, enquanto os olhares dos homens estavam ocupados

Se não é mais o tempo de fazer uma opção e se uma força superior ao homem já os arrasta, sem consultar seus desejos, na direção de um dos dois governos, procurem pelo menos tirar dele todo o bem que ele pode dar e, conhecendo os bons instintos desse governo, assim como seus maus pendores, esforcem-se por restringir o efeito dos segundos e por desenvolver os primeiros (Tocqueville, 2005: 287). 
em outras partes, colocaram-se de repente na linha de frente das nações, e o mundo tomou conhecimento quase ao mesmo tempo de seu nascimento e de sua grandeza (Tocqueville, 2005: 476).

No segundo volume de sua obra seminal, A democracia na América, Tocqueville empenhou-se em deixar claro o que é ter uma "alma" democrática. A obra é um tratado sobre educação política dirigida não apenas aos líderes da época, mas também aos líderes vindouros, isto é, aqueles a quem a possibilidade da arte de governar se apresenta. Para teóricos como Maquiavel, Hobbes, Locke e Rousseau os dirigentes políticos dependiam de suas próprias capacidades; para Tocqueville, os políticos são governados pelas circunstâncias. Esta é a nova ciência política proposta pelo pensador: de que é impossível deter a democracia, é inútil inclusive tentar, posto que ir contra a democracia é ir "contra Deus".

Tocqueville, assim como outros educadores políticos (Platão, Aristóteles e Maquiavel), procurou não apenas construir um "tipo ideal" de democracia, mas responder às razões para o sucesso da democracia americana. Já no Prefácio do primeiro volume da obra A democracia na América percebe-se que o objetivo central da obra foi tratar o advento, irresistível e universal, da democracia no mundo. Tocqueville estudou a democracia norte-americana com o intuito de compreender e tirar proveito dos exemplos bem-sucedidos daquele país, principalmente os fundamentos nos quais repousam as constituições americanas, como o princípio de ordem e equilíbrio de poderes, de profundo e sincero respeito ao direito, considerados indispensáveis a todas as repúblicas e que a todas devem ser comuns; podendo afirmar-se desde logo que, onde não se encontrarem, cedo terá a república deixado de existir.

A frase inicial de A democracia na América evidencia o grau de importância que a igualdade de condições terá para o processo democrático da era moderna: "Entre os novos objetos que me chamaram a atenção durante minha permanência nos Estados Unidos nenhum me impressionou mais do que a igualdade das condições" (Tocqueville, 2005: 7). O autor perceptivelmente cita o termo "Providência" para reafirmar o caráter histórico e universal da democracia como sendo inevitável, independentemente da vontade e do controle dos indivíduos. Alerta Tocqueville aos seus compatriotas que: "Mais cedo ou mais tarde vamos chegar como os americanos a uma igualdade de condições quase completa", pois, "a igualdade, e não a liberdade, constitui o verdadeiro 
sinal da democracia". Nesta ótica, querer deter a democracia seria como que lutar contra o próprio Deus, e só restaria às nações acomodar-se ao estado social que the impõe a Providência. Sendo assim, Tocqueville entende que "o desenvolvimento gradual da igualdade das condições é um fato providencial. Possui suas principais características: é universal, é duradouro, escapa cada dia ao poder humano; todos os acontecimentos, bem como todos os homens, contribuem para ele" (Tocqueville, 2005: 11). ${ }^{5}$

Isso não quer dizer, no entanto, que a ação humana - principalmente a ação política - não tem papel importante nas "eras democráticas". É por meio da ação política dos indivíduos que se pode tornar possível a liberdade na igualdade. Escreve Tocqueville:

A igualdade produz, de fato, duas tendências: uma leva diretamente os homens à independência e pode impeli-los de repente à anarquia, a outra os conduz por um caminho mais longo, mais secreto, porém mais seguro, à servidão (2000: 358).

\section{Caberia, então,}

Instruir a democracia, reavivar se possível suas crenças, purificar seus costumes, regular seus movimentos, substituir pouco a pouco pela ciência dos negócios sua inexperiência, pelo conhecimento de seus verdadeiros interesses seus instintos cegos; adaptar seu governo aos tempos e aos lugares; modificá-lo de acordo com as circunstâncias e os homens - este é o primeiro dever imposto nos dias de hoje aos que dirigem a sociedade (2005: 12).

Para Tocqueville, o "movimento da história" produz circunstâncias novas, e os homens devem se preparar para estas, ou seja, devem ser educados para se adaptarem às novas circunstâncias. Se os homens não se prepararem para a democracia, a fim de dirigi-la, esta crescerá abandonada, "feito criança de rua", e quando tomar o poder os seus vícios aparecerão, então os homens tentarão destruir a democracia e não corrigir os seus defeitos.

Assim é, pois, que em Tocqueville a democracia aparece como esse tipo ideal, um constructo teórico, enquanto lei intrínseca do desenvolvimento das diferentes sociedades, para a qual tendem inexoravelmente. Ela é, antes de tudo, o fim precípuo de toda sociedade que se pretenda justa, virtuosa, baseada na ideia de igualdade entre os

Para aprofundar o debate sobre o caráter providencial da democracia no mundo, conferir o trabalho de Corrêa; Cremonese (2008A). 
cidadãos. Para compreender melhor as formulações do cientista político, convém expor mais detalhadamente como se desencadeia o processo por que se consolida o ideário democrático, procedendo a uma sistematização das características observadas pelo autor no território norte-americano, a começar por seus aspectos externos e formação étnico-social.

\section{Os aspectos externos e a formação étnico-social}

Ainda na primeira parte da sua obra, Tocqueville descreve os aspectos exteriores da América, a começar por sua geografia e a formação étnica do povo. Apresenta as características do rio Mississipi, e dos vales, assim como descreve pormenores ligado aos primeiros habitantes da América, os indígenas: "O índio sabia viver sem necessidades, sofrer sem se queixar e morrer cantando" (Tocqueville, 2005: 32). Para o autor, os índios eram desprovidos de qualquer ambição material, em um estilo de vida mantido pela caça e caracterizado pela ausência de qualquer propriedade do solo: "Os índios ocupavam-no, mas não o possuíam. É pela agricultura que o homem se apropria do solo, e os primeiros habitantes da América do Norte viviam do produto da caça" (33).

Mais adiante, no segundo capítulo, Tocqueville trata da origem dos anglo-americanos e de sua importância para o futuro. Diz o autor que "Os povos sempre se ressentem de sua origem. As circunstâncias que acompanharam seu nascimento e serviram para seu desenvolvimento influem sobre todo o resto de sua carreira" (36).

Sobre o caráter de homogeneidade dos imigrantes, assim se expressa Tocqueville: "Todos os emigrantes falavam a mesma língua; todos eram filhos de um mesmo povo" (37). Porém, os emigrantes passavam por dificuldades, fator típico de pessoas que buscam outras terras (novos mundos) em busca de dias melhores e novas realidades: "Não são os felizes e os poderosos que se exilam, e a pobreza assim como o infortúnio são as melhores garantias de igualdade entre os homens que conhecemos" (38). Tocqueville cita a Virgínia como a colônia inglesa que recebeu os primeiros emigrantes, da qual chegaram no ano de 1607.

O posicionamento de Tocqueville sobre a questão da escravidão é expressamente contrário, uma vez que a considera um dos males responsáveis por desonrar o trabaIho, introduzir a ociosidade na sociedade e, com isso, a própria ignorância e o orgulho, 
além da pobreza e o luxo. Ela debilita as forças da inteligência e entorpece a atividade humana. O Sul, relata Tocqueville, era mais escravista e o Norte (Nova Inglaterra), mais desenvolvido. Os imigrantes ingleses trouxeram como característica o puritanismo religioso, além de leis severas contra a prostituição, a preguiça e o adultério. Dessa forma, o puritanismo, na abordagem de Tocqueville consistia em uma teoria política quase tanto quanto uma doutrina religiosa.

O autor entende a democracia como florescida na sociedade estadunidense já no início das colônias pelas condições sociais favoráveis dos anglo-americanos: "É eminentemente democrático. Teve esse caráter desde o nascimento das colônias e o tem mais ainda nos dias de hoje" (55). Mais à frente, no quarto capítulo, Tocqueville argumenta sobre o princípio da soberania do povo na América. Na relação das leis com a soberania popular: "Quando se quiser falar das leis políticas dos Estados Unidos, é sempre pelo dogma da soberania do povo que convém começar" (65). Acerca da fonte originária de onde emana o poder, indica Tocqueville que.

[...] O povo participa da composição das leis pela escolha dos legisladores, da sua aplicação pela eleição dos agentes do poder executivo; podemos dizer que governa por si mesmo, a tal ponto a importância deixada à administração é fraca e restrita, a tal ponto ela é marcada por sua origem popular e obedece ao poder de que emana. O povo reina sobre o mundo político americano como Deus sobre o universo. Ele é a causa e o fim de todas as coisas. Tudo provém dele e tudo nele se absorve (Tocqueville, 2005: 68).

Adiante, ainda sobre a questão da soberania popular no sistema político dos Estados Unidos: "Na América, o povo nomeia aquele que faz a lei e aquele que a executa; ele mesmo constitui o júri que pune as infrações à lei" (Tocqueville, 2005: 197). A América é retratada por Tocqueville como exemplo ideal de democracia:

A América é a terra da democracia. Os federalistas estiveram, pois, sempre em minoria; mas contavam em suas fileiras quase todos os grandes homens, que a guerra da Independência fizera nascer, e seu poder moral era muito extenso (2005: 201).

Tocqueville salienta e esclarece a diferença entre o Norte da América (manufatureiro) e o Sul, dotado de vocação eminentemente agrícola: 
[...] Assim viu-se ultimamente o Norte sustentar o sistema das proibições comerciais, e o Sul pegar em armas em favor da liberdade de comércio, pela simples razão de que o Norte é manufatureiro e o Sul cultivador e de que o sistema restritivo age em benefício de um e em detrimento do outro (2005: 203).

Em linhas gerais, percebe-se que, para o pensador, um Estado democrático, politicamente desenvolvido, só é possível de ser construído se houver a participação direta do conjunto dos cidadãos na gestão da coisa pública:

De fato, é incontestável que, nos Estados Unidos, o gosto e o uso do govemo republicano nasceram nas comunas e no seio das assembleias provinciais. [...] Cada cidadão dos Estados Unidos transporta, por assim dizer, o interesse que Ihe inspira sua pequena república para o amor à pátria comum (2005: 183).

Como vimos, Tocqueville continua descrevendo que o poder emana do povo e que este participa da composição das leis pela escolha dos legisladores e da sua aplicação mediante a eleição dos agentes do poder Executivo; pode-se dizer que ele mesmo governa, tão frágil e restrita é a parte deixada à administração, tanto se ressente esta da sua origem popular e obedece ao poder de que emana. "O povo reina sobre o mundo político americano como Deus sobre o universo. Ele é a causa e o fim de todas as coisas. Tudo provém dele e tudo nele se absorve" (Tocqueville, 2005: 68). Tocqueville entende que o povo tem o controle do governo em suas mãos: "Na América, o povo nomeia aquele que faz a lei e aquele que a executa; ele mesmo constitui o júri que pune as infrações à lei" (Tocqueville, 2005: 197). Percebe-se, no decorrer da obra, que a América é sempre tratada como o exemplo da democracia. ${ }^{6}$

Em síntese, sobre as três raças que habitaram os Estados Unidos, Tocqueville tem as seguintes posições:

Entre esses homens tão diferentes, o primeiro a atrair os olhares, o primeiro em luz, em força, em felicidade é o homem branco, o europeu, o homem por excelência; abaixo dele aparecem o negro e o índio (Tocqueville, 2005: 374).

6 Para aprofundar o debate sobre o tema da formação étnico-social dos povos norte-americanos, conferir o trabalho de Corrêa; Cremonese (2008A). 
Tocqueville, como podemos notar na afirmação acima, considera o homem branco com um ser de nível superior, enquanto o negro e o índio (animais selvagens) são considerados seres inferiores, discriminados, portanto.

Nesta parte da obra, Tocqueville volta a mencionar as diferenças entre o Sul e o Norte dos Estados Unidos. O Sul, mais escravista, e o Norte, mais industrial (navios, fábricas, estrada de ferro e canais). No Sul perdurou a escravidão por muitos anos: "O Sul poderia muito bem, a rigor, abolir a servidão; mas como se livraria dos negros?" (Tocqueville, 2005: 408).

Nos estudos de Tocqueville percebe-se que os anglo-americanos tem orgulho de pertencer a esta nação, inclusive acreditam que são um povo escolhido, diferentes dos demais povos do mundo:

Ao mesmo tempo em que são assim unidos entre si por ideias comuns, os anglo-americanos são separados de todos os outros povos por um sentimento, o orgulho. Nos últimos cinquenta anos, não se para de repetir aos habitantes dos Estados Unidos que eles constituem o único povo religioso, esclarecido e livre. Eles veem que, em seu país, as instituições democráticas até aqui prosperam, enquanto fracassam no resto do mundo; têm, pois uma opinião elevadíssima de si mesmos e não estão longe de crer que formam uma espécie à parte no gênero humano (Tocqueville, 2005: 432).

Perdoada a visão manifestadamente etnocêntrica do intelectual francês, vítima dos preconceitos de seu tempo e classe social, mantém-se em Tocqueville o fascínio pela população dos Estados Unidos da América, e em especial os puritanos, interpretados no corpus de sua obra enquanto verdadeiros "heróis", responsáveis pela construção do Novo Mundo e a coesão moral da sociedade aí instalada pelos primeiros colonos. A seção seguinte enumera de forma sintética as características observadas e atribuídas por Tocqueville à democracia norte-americana, assim como se ocupa em fornecer uma amostra de como as ideias tocquevilleanas foram recebidas no século XX, em especial na sua década final, pelo cientista político americano Robert Putnam. 


\section{O associativismo cívico como fundamento da democracia americana}

Esta seção pretende elencar as principais características da democracia americana sendo elas: a) o governo local; b) a associação cívica e, c) o espírito religioso.

Tocqueville entende o governo local ou instituições locais como o berço da democracia encontrada na comunidade, ou como ele chama: Comuna (município). É no município que se desenvolve o "espírito comunitário", o "espírito de comunidade" ou o "espírito" da cidade.

Já a associação cívica é uma das características mais importantes da democracia americana. Também chamada de "associação cívica", é o local onde existe a participação das pessoas em grupos de voluntariado. Foram estas associações cívicas de todos os tipos que impressionou Tocqueville. Para ele, estas associações são os pilares centrais da democracia: em países democráticos a ciência da associação é a ciência mãe. O progresso de todos os outros depende dela. É por meio da união dos esforços comuns que as pessoas desenvolvem o gosto da liberdade.

Diz Tocqueville que a América é o lugar em que mais se tirou partido da associação e onde se tem aplicado esse poderoso meio de ação a maior diversidade de objetos. Esta tradição associativa dos norte-americanos vem de berço: "O habitante dos Estados Unidos aprende desde o nascimento que deve contar consigo mesmo para lutar contra os males e os embaraços da vida [...]" (Tocqueville, 2005: 219). A associação visa a alcançar vários fins com o objetivo de obter a segurança pública, comércio, indústria, moral e religião. "Nada há que a vontade humana se desespere de atingir pela simples ação do poder coletivo dos indivíduos" (147). A associação é causa de união e progresso: "A associação enfeixa os esforços dos espíritos divergentes e os impele com vigor para uma única finalidade claramente indicada por ela" (147).

Esse interesse coletivo dos norte-americanos é enaltecido pelo autor francês:

De onde vem que, nos Estados Unidos, onde os habitantes chegaram ontem à terra que ocupam, aonde não levaram nem usos nem lembranças; onde se encontram pela primeira vez sem se conhecer; onde, para dizê-lo numa palavra, o instinto da pátria mal pode existir; de onde vem que todos se interessam pelos problemas de sua comuna, de seu cantão e do Estado inteiro, como se fossem os seus? (Tocqueville, 2005: 276). 
Assim, é o interesse coletivo que mais se sobressai entre os imigrantes:

Mal pisa no solo da América, você se encontra no meio de uma espécie de tumulto; eleva-se de toda a parte um clamor confuso; mil vozes chegam ao mesmo tempo a seu ouvido, cada uma das quais exprime algumas necessidades sociais. À sua volta, tudo se agita: aqui, o povo de um bairro está reunido para saber se deve construir uma igreja; ali, trabalha-se para escolher um representante; mais longe, os deputados de um cantão correm a toda pressa para a cidade, a fim de providenciar certas melhorias locais; em outro lugar, são os cultivadores de uma aldeia que abandonam seus campos para irem discutir o projeto de uma estrada ou de uma escola. Cidadãos se reúnem, com a única finalidade de declarar que desaprovam os passos do governo, enquanto outros se reúnem para proclamar que os homens no poder são os pais da pátria. Eis outros que, considerando o alcoolismo a principal fonte dos males do Estado, vêm se comprometer solenemente a dar o exemplo da temperança (2005: 283).

Tocqueville criticou, dessa forma, o centralismo das decisões das nações europeias, que fazia, segundo ele, com que o povo ignorasse os maiores acontecimentos da vida pública, bem como ficasse totalmente excluído das decisões políticas. Neste aspecto, concilia-se com os conservadores liberais, preocupando-se com a ordem, mas enfatizando a importância da autonomia nas comunidades. A participação dos indivíduos na sociedade, para ele, não se dá de maneira anárquica; isto é, a participação pressupõe a existência de uma institucionalização organizada e eficiente: é a ação contínua das leis e dos costumes, são as circunstâncias e, sobretudo, o tempo, que acabam por lhe dar solidez.

Nota-se, como referido anteriormente, que para Tocqueville os costumes de uma nação são fundamentais para que um povo democrático permaneça livre: "Meu objetivo foi mostrar, pelo exemplo da América, que as leis e, sobretudo, os costumes podiam permitir que um povo democrático permanecesse livre" (Tocqueville, 2005: 371). O grande medo de Tocqueville é que se estabeleçam instituições democráticas incapazes de dar aos cidadãos ideias e sentimentos que o preparem para a liberdade. Da mesma forma, se os governos democráticos não permitirem que os cidadãos usem sua liberdade política, não haverá independência para ninguém:

[...] nem para o burguês, nem para o aristocrata, nem para o pobre, nem para o rico, mas uma tirania igual para todos; e prevejo que, se não se conseguir, com o 
tempo, fundar entre nós o império pacato da maioria, chegaremos cedo ou tarde ao poder ilimitado de um só (Tocqueville, 2005: 371).

Tocqueville resume a ideia principal da sua obra na seguinte frase:

Tenho apenas uma palavra mais a dizer sobre esse tema. Se não consegui fazer o leitor sentir, ao longo desta obra, a importância, para a manutenção das leis, que eu atribuía à experiência prática dos americanos, a seus hábitos, a suas opiniões, numa palavra a seus costumes, falhei no objetivo principal que me propunha ao escrevê-la (Tocqueville, 2005: 363).

Mais à frente, Tocqueville argumenta sobre o empreendimento pessoal e comunitário dos americanos está em manter a democracia por meio de uma cada vez maior igualdade e liberdade; por isso, procuram esforçar-se para manter a coisa pública e a ajuda mútua:

Devo dizer que vi com frequência americanos fazerem grandes e verdadeiros sacrifícios à coisa pública, e notei centenas de vezes que, se necessário, eles quase nunca deixavam de se prestar um fiel apoio mútuo (Tocqueville, 2000: 129).

O espírito público dos americanos se sobressai, aos olhos do autor. Em outra passagem, fica ainda mais explícito o caráter associativo da vida civil dos americanos:

Os americanos de todas as idades, de todas as condições, de todos os espíritos, se unem sem cessar. Não apenas têm associações comerciais e industriais de que todos participam, mas possuem além dessas mil outras: religiosas, morais, graves, fúteis, muito gerais e muito particulares, imensas e minúsculas; os americanos se associam para dar festas, fundar seminários, construir albergues, erguer igrejas, difundir livros, enviar missionários aos antípodas; criam dessa maneira hospitais, prisões, escolas (Tocqueville, 2000: 131).

É esse espírito cívico que fez dos Estados Unidos uma democracia participativa. Jean-Jacques Chevallier (1986), igualmente, vê a importância das associações como fundamento da democracia na obra de Tocqueville. Diz o comentador que, após as liberdades locais, nada parece mais necessário a Tocqueville, e por análogas razões, do que as associações livres: o número de associações nos Estados Unidos, a diversidade de seus objetos, assombraram Tocqueville. Mostra-nos os americanos de todas as idades, 
de todas as condições, de todos os espíritos, unindo-se sem cessar para lutarem por si mesmos, sem apelo ao poder social, contra os males e dificuldades da vida. A vida escolar das crianças, os transeuntes nas ruas, a organização entre os vizinhos, construção de igrejas e bibliotecas.

A peculiaridade das associações entre os norte-americanos é o diferencial se compararmos com a França e a Inglaterra: "Nada há que a vontade humana desespere de atingir pela livre ação do poder coletivo dos indivíduos... Por toda a parte onde, à frente de uma nova empresa, vedes na França o governo e na Inglaterra um grande senhor, contai que distinguireis nos Estados Unidos uma associação" (Chevalier, 1986: 268).

Tocqueville ressalta ainda que a ação recíproca é fundamental para a edificação do sentimento comunitário: "Os sentimentos e as ideias só se renovam, o coração só aumenta e o espírito humano só se desenvolve mediante a ação recíproca dos homens uns sobre os outros" (Tocqueville, 2000: 134). Da mesma forma, "Para que os homens permaneçam ou se tornem civilizados, é necessário que entre eles a arte de se associar se desenvolva e se aperfeiçoe na mesma proporção que a igualdade de condições cresce" (Tocqueville, 2000: 136).

Outra manifestação do espírito cívico tratado por Tocqueville é a questão da liberdade de imprensa nos Estados Unidos e diz que: "Assim não há associação democrática que possa prescindir de um jornal" (Tocqueville, 2000: 138). Tocqueville aponta para a existência de uma "relação necessária entre as associações e os jornais: os jornais fazem as associações e as associações fazem os jornais", e conclui: "Por isso, a América é o país do mundo em que existem, ao mesmo tempo, mais associações e mais jornais" (Tocqueville, 2000: 138).

Este argumento de Tocqueville sobre a importância da associação cívica tem sido muito comentado pelo cientista político norte americano Robert Putnam em seus estudos na Itália e, mais tarde, nos Estados Unidos. Destes estudos destacam-se duas obras: Making democracy work: civic traditions in modern Italy (obra escrita em 1993) e Bowling Alone respectivamente.

Putnam, em Making democracy work: civic traditions in modern Italy (obra escrita em 1993), além de tratar do desempenho institucional (avaliação e explicação) e da origem da comunidade cívica, afirma que o capital social traz intrínsecas "características da organização social, como confiança, normas e sistemas, que contribuem para aumentar 
a eficiência da sociedade, facilitando as ações coordenadas" (177).7 Em outras palavras, o capital social é entendido como um dos elementos da organização social, tais como a confiança, as normas e as redes que estabelecem relações de reciprocidade, ativadas por uma confiança social que emerge das fontes, das normas de reciprocidade e das "redes de compromisso cidadão".

Putnam (2002), em sua pesquisa na Itália, entrevistou os conselheiros regionais, com o objetivo de examinar as origens do governo eficaz, quais instituições tiveram bom desempenho e quais não tiveram, na tentativa de explicar as diferenças de desempenho institucional e a relação entre desempenho e natureza da vida cívica (comunidade da vida cívica). O autor, apoiando-se na teoria tocquevilliana, argumenta que a comunidade cívica se caracteriza por cidadãos atuantes e imbuídos de espírito público, por relações políticas igualitárias e por uma estrutura social firmada na confiança e na colaboração (30-31).

Segundo Putnam (2002), em certas regiões da Itália houve maior engajamento cívico, ao passo que em outras houve uma política verticalmente estruturada, uma vida social caracterizada pela fragmentação e pelo isolamento, e uma cultura dominada pela desconfiança. Diz Putnam que primeiro é preciso conhecer as diferenças básicas da vida cívica de uma comunidade para, posteriormente, perceber o êxito ou o fracasso das instituições. Putnam acredita que a relação entre o bom desempenho institucional e a comunidade cívica leva, inexoravelmente, ao desenvolvimento da região. Mas, para chegar a um nível satisfatório de engajamento cívico e de solidariedade social, é necessário que se perceba a herança histórico-cultural da região. O capital social só foi possível ser construído graças à herança histórica que a Itália teve.

Existe virtude cívica em uma comunidade, segundo Putnam (2002), quando existe interesse pelas questões públicas e devoção às causas. Por outro lado, para caracterizar a falta de virtude cívica, Putnam apóia-se na teoria de Banfield de que uma das características da falta de virtude cívica é o familismo amoral, ou seja, "maximizar a vantagem material e imediata da família nuclear; supor que todos os outros agirão da mesma forma" (102). A característica fundamental da comunidade cívica é o seu espírito público, onde os interesses individuais estão submetidos aos interesses coletivos. Por isso, diz

As citações de Putnam foram extraídas da obra Comunidade e democracia: a experiência da Itália Moderna (2002), tradução de Making democracy work: civic traditions in modern Italy (1993). 
Putnam, "na comunidade cívica, a cidadania implica direitos e deveres iguais para todos" (102).

Da mesma forma, depois de desenvolver pesquisas em vários países, Putnam (2002) chegou à conclusão de que as pessoas que se unem em associações têm maior consciência política, confiança social, participação política e "competência cívica subjetiva", pois, conclui o autor: "tanto maior a participação em associações locais, maior a cultura cívica será; quanto maior a cultura cívica da região, mais eficaz será o seu governo" (112). Assim, o desempenho de um governo regional está, de algum modo, estritamente relacionado com o caráter cívico da vida social e política da região. Da mesma forma, o civismo tem a ver com igualdade e, também, com engajamento e dever.

Em síntese, a partir da experiência comprovada na Itália, Putnam (2002) chegou à conclusão de que existem regiões mais cívicas comparadas a outras, dependendo da maior ou menor cultura cívica. ${ }^{8}$ Configuram-se como regiões menos cívicas, geralmente, aquelas cujos cidadãos que as habitam pedem ajuda a políticos para obter licenças, empregos e assim por diante. $O$ autor cita o Sul da Itália como exemplo de regiões menos cívicas, principalmente a Púglia e a Basilicata. Nessas regiões com menor grau de civismo, a política caracteriza-se por relações verticais de autoridade e dependência, tal como corporificadas no sistema clientelista (115). Da mesma forma, as relações políticas são mais autoritárias e a participação política se restringe à elite. Putnam constatou, nas suas pesquisas, que quanto menor a participação cívica das pessoas, menor é o índice de instrução. Há uma relação aproximada entre o grau de instrução e o nível de civismo da região. Regiões menos cívicas estão mais sujeitas à corrupção (máfias). Nas regiões menos cívicas, predomina a desconfiança entre as pessoas e a vida pública organiza-se hierarquicamente. Parece ser uma conclusão lógica aquela a que Putnam chegou: quanto menor o capital social e a cultura cívica das pessoas, menor será o desenvolvimento econômico da região. A recíproca é igualmente verdadeira: quanto maior o acúmulo de capital social e maior a cultura cívica, maior será o desenvolvimento.?

8 Entende-se por cultura cívica, segundo Inglehart (1988), uma síndrome coerente de satisfação pessoal, de satisfação política, de confiança interpessoal e de apoio à ordem social existente. Essas sociedades que alcançam uma elevada posição em relação a essa síndrome têm uma maior possibilidade de aparecer como democracias estáveis, em relação a outras que têm posições mais baixas.

9 Para um debate mais aprofundado sobre a relação entre hábitos e costumes em Tocqueville e a questão do capital social em Robert Putnam, conferir o trabalho de Cremonese (2006). 
Mais tarde, em 1995, Putnam escreveu o artigo Bowling alone: the collapse and revival of American community que, em 2000, tornou-se livro. Neste, Putnam fez um estudo do capital social no seu país de origem, os Estados Unidos da América. O autor comprovou o declínio da participação (cerca de 25\%) dos americanos nas organizações políticas, religiosas, sociais, profissionais, culturais e desportivas nas últimas décadas. $O$ declínio deu-se nos grupos e associações (equipes de futebol, grupos e comunidades), tendo aumentado nas atividades de lazer individual (assistir à televisão). A participação eleitoral caiu substancialmente, sobretudo a partir dos escândalos iniciados no governo de Nixon. Mas também caiu o envolvimento em atividades locais, nas associações de pais e mestres, nos clubes, nos sindicatos, na Cruz Vermelha, nas igrejas. Curiosamente, só aumentou a prática do boliche, mesmo assim fora dos clubes. O boliche é o esporte mais popular entre os norte-americanos (80 milhões jogaram pelo menos uma vez em 1993), mas jogam cada vez mais sozinhos. Eis a razão do polêmico título do artigo de Putnam, Bowling alone ou Jogando boliche sozinho (Carvalho, 1999). As pessoas estão cada vez mais isoladas, e o esgotamento da capacidade cívica é cada vez mais visível o que tem tornado os Estados Unidos uma nação de solitários. O "bowling alone" pode ser apenas uma metáfora que transcende ao simples fato de jogar boliche sozinho.

Certamente Tocqueville jamais tenha mencionado a palavra "capital social", no entanto, isso não significa que a teorização sobre o espírito cívico dos americanos não tenha servido a estudos mais contemporâneos. É o caso do cientista político Robert Putnam e seus estudos sobre o capital social na experiência da Itália e, o estudo sobre as variáveis negativas do capital social nos Estados Unidos da América.

\section{Aspectos religiosos e educacionais}

Esta seção final dedica-se a um estudo sobre a questão da educação e das manifestações religiosas entre os norte-americanos, o que causou boa impressão no intelectual francês. Para o autor, a democracia e a religião parecem andar de mãos dadas. $\mathrm{Na}$ Europa, ocorreu o contrário, a religião e a democracia colidiam entre si. Nos Estados Unidos tem-se uma democracia puritana com fortes crenças religiosas e os hábitos que os imigrantes trouxeram para o Novo Mundo. Quase um século mais tarde o sociólogo Max Weber defenderia a tese de que a religião desapareceria com o avanço da 
modernidade com o processo de secularização. O que se percebe é Tocqueville tinha novamente razão, pois a religião tem forte influência nas relações políticas ainda em nossos dias. Segundo Tocqueville, a América não cai no despotismo da maioria, um dos maiores perigos nas eras democráticas, também por causa da religião. São os costumes e as convicções religiosas do povo dos Estados Unidos que freiam esse despotismo. "Ao cristianismo, que tornou todos os homens iguais diante de Deus, não repugnará ver todos os homens iguais diante da lei." (Tocqueville, 2005: 17). E continua: "[...] Compreendo que estes vão se apressar a chamar a religião em seu auxílio, porque devem saber que não se pode estabelecer o reinado da liberdade sem o dos costumes, nem fundar os costumes sem as crenças [...]" (17). Deriva disso que a religião funciona em um duplo sentido para o cientista político francês, isto é, como balizador da democracia, por um lado, exatamente por reforçar os costumes, e enquanto instrumento de evitação da tirania da maioria, o despotismo do povo sobre si mesmo.

Para Tocqueville o despotismo até pode ser feito sem fé, mas a liberdade não. A religião é mais que necessária em uma República ou em um país democrático, mais do que em qualquer outro. Considera o intelectual francês a crença religiosa extremamente necessária, pois, para ele, quando a religião é destruída a dúvida assume o seu lugar. Diz Tocqueville que a religião dos americanos é o que mantém as instituições políticas: "Investiguei em outro ponto desta obra as causas a que se devia atribuir a manutenção das instituições políticas dos americanos, e a religião pareceu-me uma das principais" (Tocqueville, 2000: 175).

Ao estudar as causas e as consequências da Revolução Francesa, buscando as falhas históricas deste processo e as vicissitudes sociais causadas por ele, Tocqueville rejeitou totalmente o caráter antirreligioso dos revolucionários e dos liberais em geral um caráter que considerou totalmente equivocado.

Acho que é um erro considerar a religião católica uma inimiga natural da democracia. Entre as diferentes doutrinas cristãs, o catolicismo parece-me ao contrário uma das mais favoráveis à igualdade das condições (Tocqueville, 2005: 339).

Para o pensador francês, a educação e a liberdade, nos Estados Unidos, adequaram-se ao bem, à moral e à religião. As religiões fornecem à multidão soluções para as questões do dia a dia. A multidão encontra segurança e um fundamento último para 
as suas ações. E este fundamento é importante, pois dá a todos os cidadãos ideias e sentimentos que o preparem para a liberdade. Também é participando da legislação que o americano aprende a conhecer as leis; é governando que se instrui na forma de governo. Não basta ensinar os homens a ler e escrever para fazer deles cidadãos. Os verdadeiros conhecimentos nascem da experiência, e se os americanos não tivessem sido habituados a se governar, os conhecimentos literários muito pouco serviriam. Contudo, escreve Tocqueville:

É indubitável que, nos Estados Unidos, a instrução do povo serve poderosamente para a manutenção da república democrática. Assim será, penso eu, onde quer que não se separe a instrução que esclarece o espírito da educação que regra os costumes (Tocqueville, 2005: 357).

Tocqueville é cauteloso sobre a instrução pública. Diz ele que, a educação, tanto quanto a caridade, tornou-se maior parte dos povos de nossos dias uma tarefa nacional. O Estado recebe e muitas vezes toma a criança dos braços da mãe para confiá-la a seus agentes; é ele que se encarrega de inspirar sentimentos e fornecer ideias a cada geração. A uniformidade reina nos estudos como em tudo o mais; a diversidade, como a liberdade, desaparecem deles a cada dia (Tocqueville, 2000: 376).

Assim, ao mesmo tempo em que Tocqueville vê na associação dos indivíduos um poder educativo, capaz de impedir que os indivíduos "caminhem" para a servidão, é relutante em relação à instrução pública, pois vê no domínio do Estado sobre a educação a uniformidade de ideias e a crescente burocratização do ensino. ${ }^{10}$

Mas, para Tocqueville, o maior perigo é a apatia geral, fruto do individualismo, "estado de espírito" próprio das democracias modernas. Escreve o autor (2000: 418, nota I):

Não se deve dizer de maneira absoluta e geral que o maior perigo de nossos dias seja a licença ou a tirania, a anarquia ou o despotismo. Ambos são igualmente temíveis e podem decorrer facilmente de uma só e mesma causa, que é a apatia geral, fruto do individualismo; é essa apatia que faz que o dia em que o poder executivo reúne algumas forças, está em condição de oprimir, e que, no dia seguinte, quando um partido pode pôr trinta homens em batalha, está também está em condição de

10 Isso não quer dizer que Tocqueville seja contrário a interferência do Estado na educação, pois escreve: "Tenho por certo que a educação laica é a garantia da liberdade de pensar. Creio firmemente que a Universidade deve ser o lugar principal dos estudos e que o Estado deve conservar direitos bem amplos de vigilância, inclusive sobre as escolas que não dirige..." (carta a Bouchitté, fev/1844 apud GILBERT, 1988: 144, grifos meus). 
oprimir. Como nem um nem outro podem fundar nada duradouro, o que os faz ter êxito fácil os impede de ter êxito por muito tempo. Eles se erguem porque nada a eles resiste e caem porque nada os sustenta. O que é importante combater, portanto, é muito menos a anarquia ou o despotismo do que a apatia, que pode criar quase indiferentemente um ou outro.

A apatia é combatida através do espírito cívico dos cidadãos, e este "espírito" só é possível de se efetivar nos indivíduos se estes tiverem liberdade política e participarem ativamente da coisa pública. E, como vimos, a escola, como instituição, serve para "formar cidadãos" apenas à medida que esteja inserida num contexto maior, mais geral, de cultura cívica.

Religião e educação, pilares sob os quais se sustenta o regime e o Estado democrático, despontam como condições auxiliares para a manutenção dos costumes, sentimentos e opiniões no seio da sociedade livre. Constituem os pressupostos da coesão social por toda a extensão do território norte-americano, conforme verificado por Tocqueville em suas pesquisas. Tendo isso em vista, fica suficientemente assentada a premência de tais conceitos nas elaborações do autor, confirmada, de um lado, por seus próprios escritos e informações biográficas, e de outro, pelas condições históricas da sociedade que se dispôs a estudar, os Estados Unidos da América, fortemente arraigada na religiosidade e princípios éticos trazidos pelos puritanos.

\section{Considerações finais}

Em síntese, Tocqueville, na primeira parte de sua obra A Democracia na América, publicada em 1835, trata das instituições políticas de uma sociedade democrática. Já na segunda parte, de 1840, são discutidos os componentes morais e psicológicos da democracia.

Não se encontra ninguém melhor do que Tocqueville ao estudar e particularizar a formação social americana e apontar, para além do específico, o efeito da democracia sobre os sentimentos e as opiniões daqueles que "vivem" segundo as determinações da igualdade. Isto é, a relevância das instituições sociais, políticas e religiosas para a fundamentação da democracia"1. Situado entre a queda e ascensão de dois mundos

11 Para um aprofundamento maior sobre este assunto conferir Gahyva (2006). 
diferentes, nos estertores do ancien régime, Tocqueville, sempre visionário, atuou de forma irrefutavelmente pioneira nos estudos realizados em território norte-americano, consagrando-se inserido de maneira definitiva na tradição do pensamento político ocidental.

Diferentemente da experiência francesa do pós-revolução, Tocqueville encontrou na América uma combinação entre as generalidades do estado social de igualdade e os hábitos e costumes tradicionais trazidos pelos pioneiros; cada americano sentia-se formador e parte constituinte desse estado. Tal percepção levava a população a participar ativamente das decisões administrativas. Em decorrência, os americanos desenvolveram meios alternativos de discussão e participação populares que impediram a constituição de um Estado onipresente, centralizador e aristocrático.

Nesse contexto, os costumes associativistas dos pioneiros foram decisivos na formação do espírito de liberdade americano. Vimos que o pluralismo, ao invés da centralização do poder, onde as associações equivaliam a corpos independentes que neutralizavam a tirania da maioria, predominou em suas formulações. Tanto no âmbito administrativo, quanto no político, a liberdade de associação em território americano impedia a formação de um consenso majoritário em torno de interesses comuns.

O que ficou claro a partir da construção do artigo é que a ideia básica proposta por Tocqueville era a da formação de múltiplas associações de interesses, de modo que não pudesse haver uma única que respondesse a todas as demandas do indivíduo. Consequentemente, formar-se-iam uma série de minorias que impediriam a constituição de uma maioria opressiva. Sendo assim, a manutenção do espírito associativo e participativo decorrente da tradição cultural dos norte-americanos (espírito cívico) foi fundamental para a manutenção das instituições políticas (círculo virtuoso: costumes instituições - reforço dos costumes).

Discutidos os pontos propostos, nota-se a profundidade da tese tocquevilleana, apresentada na segunda seção, da democracia como advento universal e inevitável no contexto da sociedade industrial moderna. A estruturação de tal seção foi elaborada de forma a ser complementada pelas informações sumárias, de cunho biográfico e teórico, apresentadas na primeira. Os aspectos exteriores da América do Norte foram extensamente abordados por Tocqueville, assim como as raízes étnicas da incipiente nação americana, aqui expostos resumidamente na terceira seção. Contudo, um dos 
pontos centrais da obra e do estudo tocquevilleano, assim como desta exposição, sobre a democracia na América do Norte, e de maior impacto nas ideias políticas subsequentemente desenvolvidas no século XX, foi a influência entre a cultura política do associativismo e o bom funcionamento da democracia. Para acercar-se desta problemática, dedicou-se toda a quarta seção à exposição das concepções do autor, assim como à apresentação de uma das vertentes impactadas pelas ideias de Tocqueville: Robert Putnam e o conceito de capital social. Buscou-se, assim, apresentar as diferentes matizes encontradas nas formulações do autor sobre a questão do civismo e sua relação com a democracia e a igualdade social de condições. A última seção abordou, de maneira igualmente esquemática, o entendimento do pensador acerca da correlação existente entre educação, religião e a coesão da sociedade democrática.

\section{Referências}

Aron, Raymond. 1982. As etapas do pensamento sociológico. Trad. Sérgio Bath. São Paulo: Martins Fontes; Brasília: UnB.

Carvalho, José Murilo. 1999. Boliche solitário. Disponível em: http://www1.folha.uol.com.br/ fol/brasil500/dc_6_10.htm. Acesso em: 5 de jun. 2013.

Chevalier, Jean-Jacques. 1986. As grandes obras políticas: de Maquiavel a nossos dias. Rio de Janeiro: Agir.

Correa, Ricardo; Cremonese, Dejalma. 2008A. Participação e associações livres: os fundamentos da democracia em Tocqueville. Disponível em: http://www.espacoacademico.com. br/088/88cremonese.htm. Acesso em: 6 jun. 2013.

Correa, Ricardo; Cremonese, Dejalma. Apontamentos entre democracia, educação e instrução pública em Tocqueville. 2008B. Disponível em: http://www.espacoacademico. com.br/090/90cremonese_correa.htm. Acesso em: 6 jun. 2013.

Cremonese, Dejalma. Capital social e padrões de participação político-social em ljuí - RS. 2006. Disponível em: http://www.lume.ufrgs.br/bitstream/handle/10183/7623/000549817. pdf?sequence=1. Acesso em: 6 jun. 2013.

Gahyva, Helga. 2006. Tocqueville e Gobineau no mundo dos iguais. In. Dados. Rio de Janeiro, vol. 49, n. 3 . 
Galvão Quirino, Célia. 2001. Tocqueville: sobre a liberdade e a igualdade. In: Weffort, Francisco (Org.). Os clássicos da política. São Paulo: Ática, vol. 2.

Gaspar, Carlos. Lições de Tocqueville. In: Instituto Português de Relações Internacionais - IPRI.

Jul./ 2005. Disponível em: <http:// www.lpri.pt/ investigadores /artigo.php?idi=3\&ida=124>. Acesso em: 22/05/2008.

Gilbert, Pierre. 1988. Igualdade social e liberdade política: uma introdução à obra de Alexis de Tocqueville. Trad. Cícero Araújo. São Paulo: Nerman.

Inglehart, Ronald. 1988. "The Renaissance of Political Culture", American Political Science Review, v. 82, n. 4, diciembre.

Rothstein, Bo. 2000. Political institutions: an overview. In: Goddin, Robert E.; Klingemann, Hans-Dieter. A new handbook of Political Science. New York: Oxford University Press. p. $150-151$

Tocqueville, Alexis de. 2005. A democracia na América: leis e costumes de certas leis e certos costumes políticos que foram naturalmente sugeridos aos americanos por seu estado social democrático. Tradução de Eduardo Brandão; prefácio, bibliografia e cronologia por François Furet. 2. ed. São Paulo: Martins Fontes, (Paidéia).

Tocqueville, Alexis de. 2000. A democracia na América: sentimentos e opiniões: de uma profusão de sentimentos e opiniões que o estado social democrático fez nascer entre os americanos. Tradução de Eduardo Brandão. São Paulo: Martins Fontes, (Paidéia).

Tocqueville, Alexis de. 1997. O antigo regime e a revolução. 4. ed. Brasília: Editora Universidade de Brasília. 